\title{
Diversity of Bacillus-like organisms isolated from deep-sea hypersaline anoxic sediments Andrea M Sass ${ }^{1,2}$, Boyd A McKew ${ }^{1}$, Henrik Sass ${ }^{3}$, Jörg Fichtel ${ }^{4}$, Kenneth N Timmis ${ }^{1,5,6}$ and Terry J McGenity*1
}

\author{
Address: ${ }^{1}$ Department of Biological Sciences, University of Essex, Wivenhoe Park, Colchester CO4 3SQ, UK, ${ }^{2}$ School of Biosciences, Cardiff \\ University, Cardiff CF10 3YE, UK, ${ }^{3}$ School of Earth Ocean \& Planetary Science, Cardiff University, Cardiff CF10 3YE, UK, ${ }^{4}$ Institute for Chemistry \\ and Biology of the Marine Environment (ICBM), University of Oldenburg, D-26111 Oldenburg, Germany, ${ }^{5}$ Helmholtz Center for Infection \\ Research, Inhoffenstrasse 7, D-38124 Braunschweig, Germany and ' Institute for Microbiology, Technical University Braunschweig, Germany \\ Email: Andrea M Sass - sassam@Cardiff.ac.uk; Boyd A McKew - bamcke@essex.ac.uk; Henrik Sass - sassh@earth.cf.ac.uk; \\ Jörg Fichtel - joerg.fichtel@icbm.de; Kenneth N Timmis - Kenneth.Timmis@helmholtz-hzi.de; Terry J McGenity* - TJMcGen@Essex.ac.uk \\ * Corresponding author
}

Published: 9 June 2008

Saline Systems 2008, 4:8 doi:10.1186/1746-1448-4-8

This article is available from: http://www.salinesystems.org/content/4/I/8

(C) 2008 Sass et al; licensee BioMed Central Ltd.

This is an Open Access article distributed under the terms of the Creative Commons Attribution License (http://creativecommons.org/licenses/by/2.0), which permits unrestricted use, distribution, and reproduction in any medium, provided the original work is properly cited.
Received: I February 2008
Accepted: 9 June 2008

\begin{abstract}
Background: The deep-sea, hypersaline anoxic brine lakes in the Mediterranean are among the most extreme environments on earth, and in one of them, the $\mathrm{MgCl}_{2}$-rich Discovery basin, the presence of active microbes is equivocal. However, thriving microbial communities have been detected especially in the chemocline between deep seawater and three $\mathrm{NaCl}$-rich brine lakes, I'Atalante, Bannock and Urania. By contrast, the microbiota of these brine-lake sediments remains largely unexplored.

Results: Eighty nine isolates were obtained from the sediments of four deep-sea, hypersaline anoxic brine lakes in the Eastern Mediterranean Sea: I'Atalante, Bannock, Discovery and Urania basins. This culture collection was dominated by representatives of the genus Bacillus and close relatives ( $90 \%$ of all isolates) that were investigated further. Physiological characterization of representative strains revealed large versatility with respect to enzyme activities or substrate utilization. Two third of the isolates did not grow at in-situ salinities and were presumably present as endospores. This is supported by high numbers of endospores in Bannock, Discovery and Urania basins ranging from $3.8 \times 10^{5}$ to $1.2 \times 10^{6} \mathrm{~g}^{-1} \mathrm{dw}$ sediment. However, the remaining isolates were highly halotolerant growing at salinities of up to $30 \% \mathrm{NaCl}$. Some of the novel isolates affiliating with the genus Pontibacillus grew well under anoxic conditions in sulfidic medium by fermentation or anaerobic respiration using dimethylsulfoxide or trimethylamine $\mathrm{N}$-oxide as electron acceptor.
\end{abstract}

Conclusion: Some of the halophilic, facultatively anaerobic relatives of Bacillus appear well adapted to life in this hostile environment and suggest the presence of actively growing microbial communities in the $\mathrm{NaCl}$-rich, deep-sea brine-lake sediments.

\section{Background}

Numerous basins filled with highly saline, anoxic waters have been discovered on the seafloor of the Eastern Med- iterranean Sea, the Red Sea and the Gulf of Mexico. Within the Eastern Mediterranean the hypersaline brine lakes are situated on the Mediterranean Ridge, a submarine moun- 
tain chain emerging from subduction processes at the collision zone of the African and European tectonic plates [1]. Tectonic processes have resulted in folded and deformed sediments leading to seawater coming into contact with evaporites that were deposited during the Messinian salinity crisis ( 5.96 to 5.33 million years ago) $[2,3]$. The outcropping salt is dissolved and the resulting highly saline brines can accumulate in depressions in the seafloor [1]. Owing to the weak currents at such a depth and the large difference in density, the hypersaline brines do not mix with the overlying seawater, forming an extremely steep chemocline at the interface with a vertical extension of about 2 meters [4]. The hypersaline brine lakes are unique and hostile environments, characterized by extremely high salt concentrations, anoxia with high sulfide concentrations, and the high pressure typical of a deep-sea environment [5].

Four of the basins in the Eastern Mediterranean Sea, l'Atalante, Bannock, Discovery and Urania basins (Fig. 1) have been sampled and studied to better understand their biogeochemistry, ecology and biotechnological potential. The physico-chemical properties of the hypersaline brine lakes have been described by van der Wielen et al. [5], but in brief l'Atalante and Bannock brines contain ions roughly in proportion to those found in seawater but almost at the point of sodium chloride saturation ( $~ 8$ times seawater concentration). The Urania brine has a slightly lower salinity, but exhibits one of the highest sulfide concentrations measured in marine environments $[5,6]$; it also has a very high methane concentration and in parts an elevated temperature, possibly caused by a deep source of the brine [7]. The Discovery basin is unique in

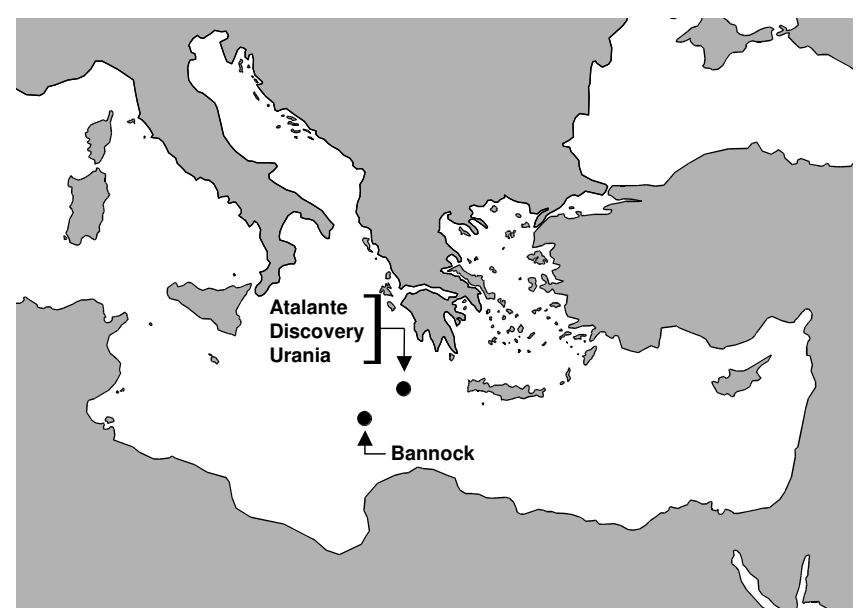

Figure I

Location of the four deep-sea hypersaline anoxic basins within the Eastern Mediterranean Sea (coordinates for the basins: L'Atalante 35.18 N 21.4I E, Discovery 35.17 N 21.4I E, Urania 35.14 N 2I.3I E, Bannock 34.17 N 20.00 E). that it derives from bischofite $\left(\mathrm{MgCl}_{2} \cdot 6 \mathrm{H}_{2} \mathrm{O}\right)$, resulting in a 5 Molar magnesium chloride brine [8], representing the marine environment with the lowest reported water activity [9].

Microbial activity within the basins has been demonstrated by hydrolytic enzyme activities, methanogenesis and sulfate reduction in all four basins [5], and depletion of ${ }^{34} \mathrm{~S}$ in sulfide, indicating microbial sulfate reduction in Urania Basin $[6,10]$. However, in the $\mathrm{MgCl}_{2}$-rich Discovery brine lake, Hallsworth et al. [9] did not detect messenger RNA coding for enzymes central to sulfate reduction and methanogenesis, and attributed this to the chaotropic nature of $\mathrm{MgCl}_{2}$. In contrast, the seawater - brine-lake interfaces for Bannock and l'Atalante basins have diverse and active microbial communities largely dominated by Bacteria [11,12]; and novel esterases that function at high pressure and over a wide range of salinities are indicative of microbes specifically adapted to the steep, deep-sea halocline between seawater and Urania brine lake [13]

In the sediments of l'Atalante brine-lake, viral abundance and virus to prokaryote abundance ratio are similar to those reported in oxic, deep-sea sediments [14]. The phospholipid-linked fatty acid (PLFA) compositions of the brine-lake sediments from Bannock, Urania and l'Atalante are similar to each other, and distinct from the PLFA composition of Discovery brine-lake sediment, which is more typical of deep-sea Mediterranean sediments outside of the hypersaline brines [15]. To date, a small number of cultured microorganisms has been reported, primarily from the seawater-brine lake interface of Bannock and Urania basins $[6,11,16-18]$, but during these studies no isolates had been obtained from the brine-lake sediments. One of the aims of our study was to investigate the microbiota of the brine-lake sediments, and many isolates were obtained from sediments of all four basins, with the vast majority being spore-forming bacteria related to the genus Bacillus.

Members of the order Bacillales are found in almost every environment on earth from the stratosphere [19] to the deep subsurface [20-22]. This ubiquity is, in part, attributed to their ability to form resilient spores that can be transported over long distances [23], but a frequently overlooked feature of the order Bacillales is their great metabolic versatility and ability to grow under physico-chemical extremes. In this study we focus on the Bacillus-related isolates from the brine-lake sediments. Such deep-sea topographical depressions will collect all sorts of material, including bacterial spores, but here we provide evidence that some of the microbes from the brine-lake sediments have the potential to be active in situ. 


\section{Results and Discussion Sediment characteristics}

In contrast to the oxidized sediments in the vicinity of the basins, which had a beige-brown colour at the top, the anoxic sediments within the l'Atalante and Bannock basins were dark grey with a black surface layer approximately $1-\mathrm{cm}$ thick, that was less compacted than the underlying layer and very easily disturbed. The top layer of the Discovery basin sediments was jet-black, and also not very compacted and very viscous owing to the high magnesium chloride content. There was no obvious layering of this sediment. The sediments of the Urania basin in contrast were of a light grey color. Gas bubbles developed in the Urania sediment shortly after retrieval of the multicorer, possibly due to out-gassing of methane or carbon dioxide under atmospheric pressure. The upper two centimeters of the anoxic sediments were nearly liquid, so they could only be sampled with a pipette and it was not necessary to mix the sediment with ambient water to form slurries before processing.

\section{Viable cell count}

The highest colony-forming units (CFU) per ml of sediment were observed on artificial seawater, with estimated numbers of $1.1 \times 10^{4}$ for l'Atalante, $4.5 \times 10^{3}$ for Bannock, $1.3 \times 10^{3}$ for Urania and $5 \times 10^{2}$ for Discovery basins. The number of CFU was generally one order of magnitude lower on medium with elevated salinity $(12 \%$, medium $\mathrm{B} / 2$ ) than on artificial seawater. No growth was observed on medium B with $24 \%$ salinity. Total cell counts were not available from this study, but Sass [24] obtained a total cell count from Urania basin sediment of $3.6 \times 10^{7}$ cells $\mathrm{ml}^{-1}$ which was similar to counts obtained by Danovaro et al. [14] for l'Atalante basin sediments $\left(5.7 \times 10^{7}\right.$ cells $\mathrm{ml}^{-1}$; converted using a density value of $1.23 \mathrm{~g} \mathrm{ml}^{-1}$ [5]), indicating that we cultivated about 0.004 to $0.02 \%$ of the microbes in the sediment.

The lowest counts were found in Discovery brine-lake sediment, and given that $5 \mathrm{M} \mathrm{MgCl}_{2}$ inhibits growth but preserves cell structure [9], it can be assumed that this provides a baseline for inactive but culturable microorganisms in the basin. This is supported by the findings of Polymenakou et al. [15] that PLFA profiles from sediments in the Discovery basin were similar to those from 'normal' hemipelagic Mediterranean sediments, suggesting that the majority of the source organisms for the PLFA were introduced into the basin by sedimentation or lateral flows. Sediments of the other three basins (l'Atalante, Bannock and Urania) had PLFA patterns that clearly differed from those of sediments outside the brine lakes revealing distinct and probably active communities [15]. Two questions emerge from these observations: were isolates similar between the four basins, and do they demonstrate the potential to be active in situ?

\section{Number and affiliation of isolates}

A total of 89 strains were isolated from the sediment samples (29 from l'Atalante, 30 from Bannock, 16 from Discovery, and 14 from Urania basins). Screening by Amplified Ribosomal DNA Restriction Analysis (ARDRA) and partial sequencing of the $16 \mathrm{~S}$ rRNA genes revealed that 80 strains ( $90 \%$ of those isolated) were related to the Bacillales. The other nine strains were related to Halomonas aquamarina (4 strains), Pseudomonas sp. (4 strains) and Alteromonas sp. (1 strain). Since Alteromonas and Halomonas spp. were previously shown to be dominant organisms in the chemocline but less abundant in the brine [6] we assume that they were not indigenous sediment bacteria but introduced by sedimentation. Spore-forming bacteria however were more typically isolated from brine-lake sediments, and only rarely from the chemocline (data not shown). Therefore, in the present study we focused on isolates affiliating with the Bacillales. Out of the 80 strains from the Bacillales 25 representative strains with differing ARDRA profiles were selected for physiological characterization and detailed phylogenetic analysis. Of these 25 ARDRA groups, 17 were from one basin only, six were found in two basins, and two were found in three basins. There were no clear trends in the distribution of the isolates in the different basins; however, although numbers are relatively small, it is notable that one of the ARDRA groups represented by strain AS5, had 14 strains that were isolated only from l'Atalante and Bannock basins, the most geochemically similar, yet geographically distant basins.

Most of these Bacillus-like isolates are closely related to previously cultivated organisms (Fig. 2), many of which are moderately halophilic or alkaliphilic. Six strains (from l'Atalante, Urania and Bannock, but not from Discovery basin) belong to a cluster accommodating genera with many halotolerant representatives like Halobacillus, Virgibacillus and Pontibacillus (see Fig. 2) [25,26]. All of these strains were isolated on a medium with elevated salt concentration $(12 \% \mathrm{NaCl})$.

\section{Phenotypic and physiological diversity of isolates}

The isolates were Gram-positive and, with the exception of strain BS3, formed endospores. All but four isolates were found to be motile by peritrichous flagella (Table 1). The pairs of strains that were phylogenetically most similar, such as AS2 and AS3, US2 and US4, US7 and BS29, and AS6 and BS6 (Fig. 2) were also phenotypically most similar (Fig. 3). The isolates were physiologically diverse (Table 1) particularly when considering their enzyme activities and substrate utilization capacities (Table 1). Generally, the isolates grew well on yeast extract, peptone, casamino acids and a range of carbohydrates and amino acids, while fatty acids or alcohols were less commonly used. A few strains grew also on aromatic compounds or 


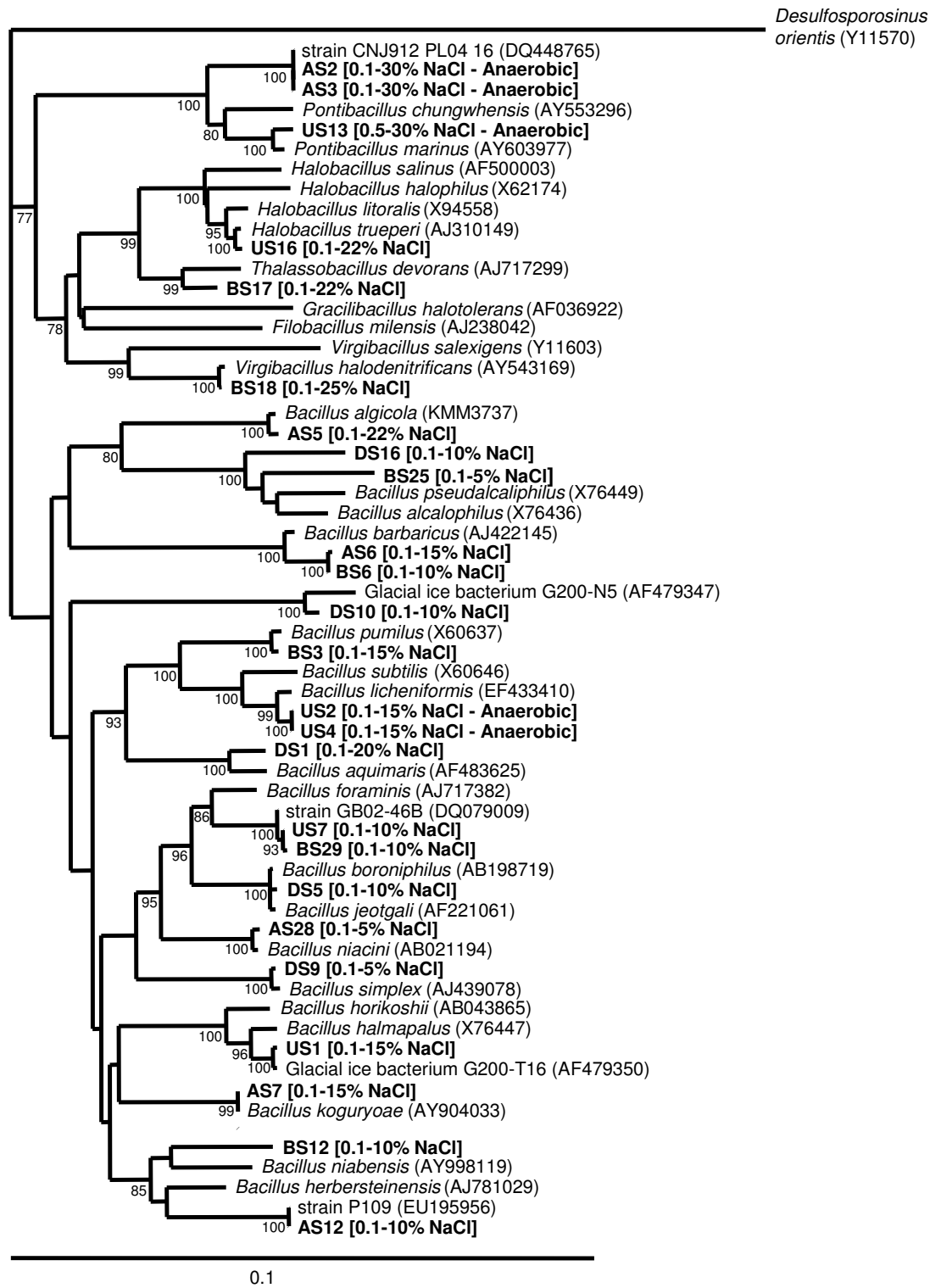

Figure 2

Phylogenetic tree based on I6S rRNA sequences of isolates from l'Atalante (AS), Bannock (BS), Discovery (DS) and Urania (US) brine-lake sediments. The tree was constructed based on an alignment of approximately 1340 base pairs from the isolates and their closest relatives. Uncharacterized strains were included in the tree when there was no closely related named species. For the named species, the sequence from the type strain was used. Accession numbers of reference strains are given in round brackets. The scale bar corresponds to 0.1 substitutions per nucleotide position. Figures (\%) at branching points represent significance of branching order by bootstrap analysis (1000 replicates, bootstrap values above $75 \%$ are shown). For the strains isolated from the deep-sea brine-lake sediments, the $\mathrm{NaCl}$ range for growth and the ability to grow under anaerobic conditions are indicated in square brackets. Note that while strain USI 3 did not grow fermentatively, it grew using dimethylsulfoxide or trimethylamine $\mathrm{N}$-oxide as electron acceptor.

$n$-alkanes. Compared with the other isolates, strains DS1 and DS5 had limited catabolic capabilities, growing only on five and three substrates, respectively. Interestingly, one of them (strain DS1) grew well on $n$-alkanes.

All strains were mesophilic, growing between 12 and $37^{\circ} \mathrm{C}$, indicating that they could grow within the temperature range experienced at the surface of the Mediterra- nean and the deep-sea, including the brine lakes which have a temperature of 13.9 to $16.7^{\circ} \mathrm{C}$ [5]. Some isolates also grew at $4^{\circ} \mathrm{C}$, whereas others grew at 45 or even $53^{\circ} \mathrm{C}$ (Table 1). With the exception of strain US13 (minimum salinity for growth of $0.5 \% \mathrm{NaCl}$ ), all strains grew in media containing only $0.1 \% \mathrm{NaCl}$, and most had a growth optimum between 1 and $5 \% \mathrm{NaCl}$, suggesting that they were marine and incapable of growth in the brine- 


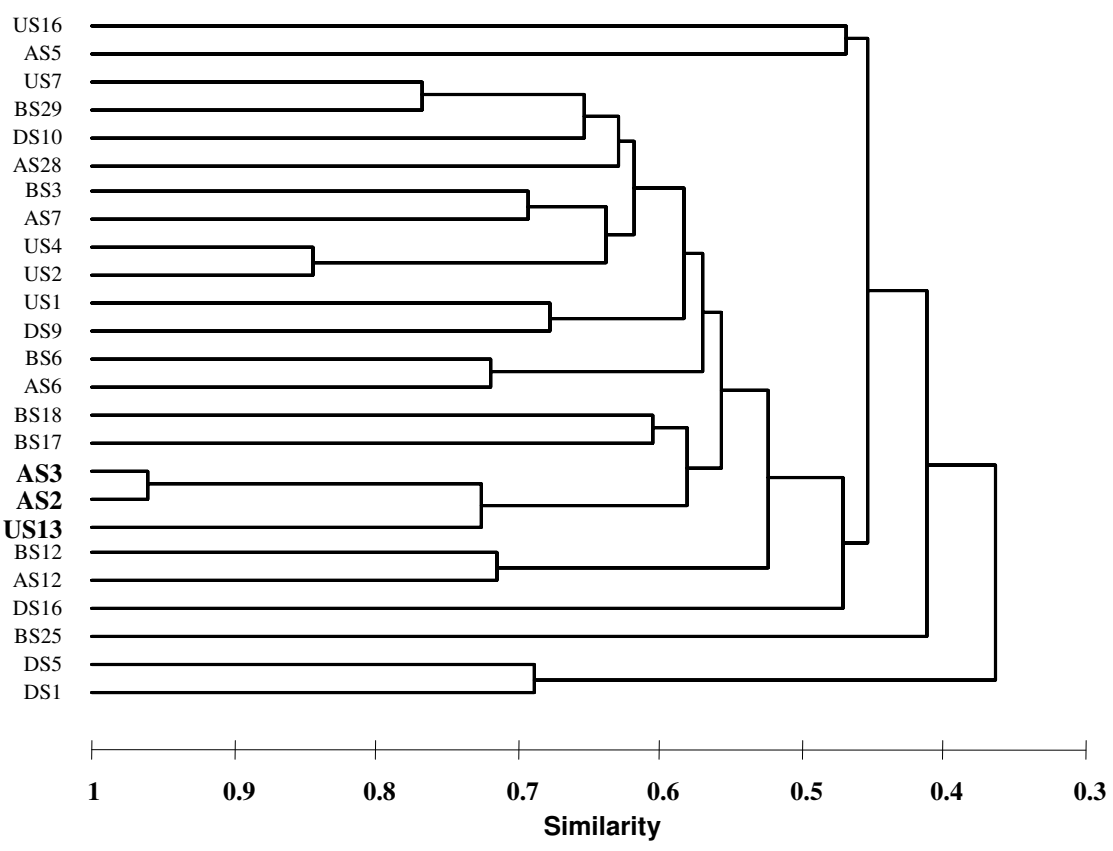

Figure 3

Dendrogram showing the phenotypic similarity of the isolates from l'Atalante (AS), Bannock (BS), Discovery (DS) and Urania (US) brine-lake sediments, based on 106 physiological and biochemical tests (see Methods). Similarities calculated with the AHC method, using the Jaccard coefficient and UPGA linkage. Clustering of the extremely halotolerant isolates AS2, AS3 and USI 3 (bold text) confirms their close phenotypic similarity in addition to their close phylogentic relationship (see Fig. 2).

lake sediments. None of the five isolates from Discovery brine-lake sediment grew in media with an $\mathrm{MgCl}_{2}$ concentration exceeding $7.5 \%$, and therefore were not adapted to in-situ conditions. However, the eight strains isolated on medium $\mathrm{B} / 2$ with $12 \% \mathrm{NaCl}$ were generally the most halotolerant (Table 1). Three of these strains (AS2, AS3 and US13) were capable of growing at extremely high salt concentrations, similar to those in the basins. They grew up to $30 \% \mathrm{NaCl}$ with an optimum of $10-15 \% \mathrm{NaCl}$. Strains AS2 and AS3 also grew by fermentation in anoxic artificial seawater as well as in medium with $20 \% \mathrm{NaCl}$ (Table 1), and all three strains (AS2, AS3 and US13) could use dimethylsulfoxide and trimethylamine $\mathrm{N}$-oxide as terminal electron acceptors (data not shown).

\section{Are the brine-lake sediment communities dominated by inactive endospores?}

The high proportion of Bacillus-related strains among the isolates in this study, although no pasteurisation was performed to select for spore formers, suggests that many the Bacillus-like isolates might originate from dormant endospores and that most of the non-spore-forming marine microorganisms that might drift into the brine do not survive. This is supported by the general lack of correlation between the affiliation of the isolates and the basin of origin, and especially by failure of many strains to grow at in-situ salinities. Endospores can be stained by the commonly used dyes like acridine orange and DAPI [27], and so can be expected to contribute to the total cell counts. Endospore numbers were estimated from dipicolinic acid (DPA) contents [28] in sediment samples from the Urania $\left(3.8 \times 10^{5} \mathrm{~g}^{-1} \mathrm{dw}\right.$ sediment $)$, Bannock $\left(9.0 \times 10^{5} \mathrm{~g}^{-1} \mathrm{dw}\right.$ sediment) and Discovery $\left(1.2 \times 10^{6} \mathrm{~g}^{-1} \mathrm{dw}\right.$ sediment $)$ basins. These numbers are lower than those obtained from highly active coastal sediments where endospores were estimated to represent up to $3 \%$ of the total cell counts [28]. However, considering the low total cell counts in the range of 2.6 and $5.7 \times 10^{7}$ cells $\mathrm{ml}^{-1}$ (note the different unit) in the brine-lake sediments it is apparent that the contribution of endospores to the brine-lake sediment microbial communities is in the same range (up to $5 \%$ of the total cell counts).

The capacity to form endospores may explain why Bacillus-like organisms can be isolated from almost all types of environment, e.g. soils, sediments, foods and water [29], including extreme environments like solar salterns [30,31], deep-sea hydrothermal vents [32] or brine-lake sediments (this study). Whether they play an important ecological role in most of these environments remains a matter of debate. In studies using a combination of culture-dependent and -independent methods members of 


\begin{tabular}{|c|c|c|c|c|c|c|c|c|c|c|c|c|c|c|c|c|c|c|c|c|c|c|c|c|c|}
\hline & \multicolumn{7}{|c|}{ L'Atalante } & \multicolumn{7}{|c|}{ Bannock } & \multicolumn{5}{|c|}{ Discovery } & \multicolumn{6}{|c|}{ Urania } \\
\hline & AS2 & AS3 & AS5 & AS6 & AS7 & ASI2 & AS28 & BS3 & BS6 & BSI2 & BS17 & BSI8 & BS25 & BS29 & DSI & DS5 & DS9 & DSIO & DS16 & USI & US2 & US4 & US7 & USI3 & US 16 \\
\hline $\begin{array}{l}\text { Salinity of isolation medium [\% } \\
\mathrm{NaCl}]\end{array}$ & 12 & 12 & 12 & 3.5 & 3.5 & 3.5 & 3.5 & 3.5 & 3.5 & 3.5 & 12 & 12 & 3.5 & 3.5 & 12 & 3.5 & 3.5 & 3.5 & 3.5 & 3.5 & 3.5 & 3.5 & 3.5 & 12 & 12 \\
\hline $\operatorname{Max} . \mathrm{NaCl}$ [\%] & 30 & 30 & 22 & 15 & 15 & 10 & 5 & 15 & 10 & 10 & 22 & 25 & 5 & 10 & 20 & 10 & 5 & 10 & 10 & 15 & 15 & 15 & 10 & 30 & 22 \\
\hline \multicolumn{26}{|l|}{ Growth at } \\
\hline $4^{\circ} \mathrm{C}$ & - & - & - & - & - & + & - & - & - & - & - & - & - & - & + & + & + & + & - & + & - & - & - & - & - \\
\hline $45^{\circ} \mathrm{C}$ & + & + & - & + & + & - & + & + & + & - & + & + & - & + & + & + & + & + & - & + & + & + & + & + & - \\
\hline $53^{\circ} \mathrm{C}$ & - & - & - & - & - & - & - & + & - & - & - & - & - & - & - & - & - & - & - & - & + & + & - & - & - \\
\hline $\mathrm{pH} 5.5$ & + & + & + & + & + & + & + & + & + & + & + & + & - & - & + & + & + & + & - & + & + & + & - & - & - \\
\hline $\mathrm{pH} 6.5$ & + & + & + & + & + & + & + & + & + & + & + & + & - & + & + & + & + & + & - & + & + & + & + & - & + \\
\hline $\mathrm{pH} 9.0$ & + & + & + & + & + & + & - & + & + & + & + & + & + & + & + & + & + & + & + & + & + & + & + & + & + \\
\hline Fermentation') & + & + & - & - & - & - & - & - & - & - & - & - & - & - & - & - & - & - & - & - & + & + & - & - & - \\
\hline Motility & + & + & + & + & + & + & - & + & + & + & + & + & + & - & + & + & - & + & + & + & + & + & - & + & + \\
\hline \multicolumn{26}{|l|}{ Enzyme activity } \\
\hline Polymer degr.2) & 2 & 2 & 4 & 4 & 4 & 2 & 3 & 4 & 3 & 2 & 3 & 2 & 0 & 5 & 5 & 4 & 4 & 3 & 1 & 4 & 6 & 6 & 5 & 2 & 3 \\
\hline Nitrite prod. & - & - & - & - & - & + & + & - & - & - & - & + & + & + & + & + & - & - & - & - & + & + & + & - & + \\
\hline$\beta$-Galactosidase & + & + & + & + & + & + & + & - & + & + & - & + & + & + & + & + & - & + & - & - & + & + & + & - & + \\
\hline Arginine dehyd. & - & - & - & - & - & - & - & - & - & - & - & - & + & - & - & - & - & - & - & - & + & + & - & - & - \\
\hline Urease & - & - & - & - & - & - & + & - & - & - & - & + & - & - & - & - & - & + & + & - & + & - & - & - & - \\
\hline Acetoin prod. & - & - & - & + & + & + & + & + & + & + & + & + & + & + & + & + & + & + & + & + & + & + & + & + & - \\
\hline Catalase & + & + & + & + & + & + & + & + & + & + & + & + & + & + & - & + & + & + & - & + & + & + & + & + & - \\
\hline Oxidase & - & - & - & - & - & + & + & - & - & + & + & + & - & - & - & - & + & - & - & + & + & - & - & + & - \\
\hline \multicolumn{26}{|l|}{ Substrate utilization ${ }^{3)}$} \\
\hline Poly- and disaccharides (8) & 5 & 5 & 5 & 7 & 6 & 5 & 6 & 5 & 6 & 6 & 6 & 6 & 6 & 6 & 0 & 0 & 6 & 5 & 3 & 6 & 4 & 4 & 6 & 4 & 6 \\
\hline Monosaccharides (14) & 9 & 9 & 5 & 6 & 8 & 9 & 8 & 9 & 5 & 9 & 10 & 9 & 6 & 8 & 3 & 1 & 12 & 13 & 11 & 10 & 12 & 12 & 9 & 9 & 10 \\
\hline Alcohols (5) & 1 & 1 & 0 & 1 & 1 & 1 & 1 & 1 & 1 & 1 & 2 & 1 & 1 & 1 & 1 & 1 & 5 & 3 & 0 & 1 & 1 & 1 & 1 & 1 & 1 \\
\hline Fatty acids (4) & 0 & 0 & 0 & 0 & 1 & 0 & 1 & 0 & 0 & 0 & 2 & 1 & 0 & 1 & 0 & 0 & 2 & 1 & 0 & 2 & 0 & 0 & 4 & 0 & 0 \\
\hline Carboxylic acids (7) & 5 & 5 & 0 & 5 & 6 & 0 & 3 & 4 & 5 & 2 & 6 & 7 & 0 & 7 & 1 & 1 & 7 & 7 & 6 & 4 & 6 & 4 & 7 & 6 & 0 \\
\hline Amino acids (20) & 7 & 7 & 0 & 8 & 6 & 0 & 4 & 5 & 3 & 2 & 9 & 0 & 7 & 3 & 0 & 0 & 5 & 8 & 5 & 7 & 4 & 4 & 6 & 4 & 7 \\
\hline Betaine, Salicylate, benzoate & 0 & 0 & 0 & 0 & 0 & 0 & 0 & 0 & 0 & 0 & 2 & 2 & 0 & 0 & 0 & 0 & 0 & 1 & 0 & 0 & 0 & 0 & 0 & 0 & 1 \\
\hline Alkanes (2) & 0 & 0 & 0 & 0 & 0 & 0 & 0 & 0 & 0 & 0 & 0 & 0 & 2 & 0 & 2 & 0 & 0 & 0 & 0 & 0 & 0 & 0 & 0 & 0 & 0 \\
\hline
\end{tabular}

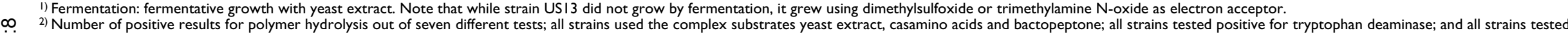

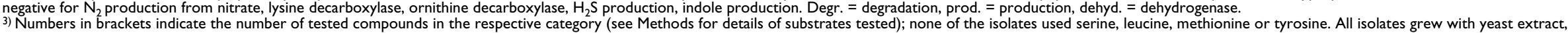
peptone and casamino acids. 
the Bacillales are often found among the isolates, but rarely in DNA-based detection methods [33,34], suggesting that spore-forming bacteria are easily cultivated with standard methods although they represent only a small proportion of the microbial community. This might be explained by the fact that bacteria in most environments are strongly energy-limited, and it was shown that starved cells can be severely harmed by a substrate shock after exposure to high substrate concentrations as found in many standard media [35]. In contrast, endospores do contain enough energy for germination and are specifically adapted to quickly respond to substrate availability and by forming a vegetative cell they are able to proliferate. Therefore, it can be expected that they can easily outgrow other organisms after transfer onto microbiological media. On the other hand, endospores possess a very rigid and resistant cell wall and it is unclear to what extent endospores are successfully lysed and extracted using standard nucleic-acid extraction procedures [e.g. [36]]. The spores themselves may have an important ecological role, especially as they contribute to such a high proportion of total counts in sediments. For example, spores have been shown to catalyse the oxidation of $\mathrm{Mn}^{2+}$ [37].

Spores of Bacillus-like organisms can rest dormant for long time periods and they are resistant to damage through desiccation and radiation for example [23]. Bacillus-like organisms have been isolated from deep subsurface sediments $[21,22]$ and from inclusions inside materials like amber [38], salt crystals [39] or glacial ice $[40,41]$ where the spores must have been included since the time of deposition. The age of the inclusions in the salt crystals and amber was estimated in the range of several million years $[38,39]$, the age of those in glacial ice in the range of 5 to 750,000 years $[40,41]$.

Therefore, the spores in the basin sediments may have drifted into the brines from environments far from the deep-sea hypersaline anoxic basins, accumulated in the brine-lake sediments and remained viable. The high salinity within the brine lakes could even have enhanced the preservation of the spores $[9,14,42,43]$. Alternatively it can be envisaged that they originate from the evaporites, as viable spores were reported from salt deposits tens of millions of years old [39], far older than the Messinian evaporates beneath the Mediterranean Sea.

\section{Evidence for active members of the Bacillales in brine-lake sediments}

About two thirds of the strains tested did not grow under in-situ salinities and probably derived from dormant spores, whereas seven strains were very halotolerant and grew at salinities close to in-situ values. However, in the fermentation assay only two of these (strains AS2 and AS3) formed cultures turbid enough for photometric anal- ysis. This is not unusual; many anaerobic bacteria form only low biomass. This can be explained by the low energy yield available from many fermentations. Otherwise many bacteria may rely on the activity of a syntrophic partner which is lacking when grown in pure cultures. An example of such bacteria are strains related to the genus Rhizobium isolated under anoxic conditions from Mediterranean sediments [44]. None of these formed turbid cultures under anoxic conditions. Rhizobium-related organisms were unexpected for deep-sea sediments, but were proven to be abundant members of the sediment microbial communities by quantitative PCR [45]. Whether the same is true for the Bacillus-like organisms in the brine-lake sediments needs to be investigated further. In any case, our data confirm that it is possible to isolate Bacillus-like strains that are physiologically capable of growing under the conditions in the brine, i.e. extremely high salinity combined with anoxia and a sulfide concentration of several millimol per liter.

\section{Conclusion}

The topography of deep-sea hypersaline anoxic basins makes them excellent collecting bowls for material sinking from the surface and slumping from surrounding sediments. Most of the organisms entering the brine lake will be unable to tolerate the extreme salinity or high sulfide concentrations and so will die and release their cellular contents. This, together with the combined preservation effects of anoxia and low water activity, explains why l'Atalante brine-lake sediment has the highest concentration of extracellular DNA reported in a natural environment [14]. Spores, however, are better equipped to survive environmental shocks, explaining why we isolated such a high proportion of endospore-forming Bacillus-like organisms from the brine-lake sediments. Discovery brine lake, an almost saturated $5 \mathrm{M} \mathrm{MgCl}_{2}$ brine, is the most chaotropic large-scale environment on earth, and has the lowest water activity of any marine environment [9]. There is, however, conflicting evidence of microbial activity $[5,9]$ in Discovery hypersaline brine. Several lines of evidence suggest that microbial activity is not favored in Discovery basin: undetectable mRNA from sulfate-reducing bacteria and methanogens compared with the upper part of the chemocline and l'Atalante basin [9], similarity of PLFA profiles with deep-sea sediments outside of the hypersaline brine [15], and the high redox potential (10 $\mathrm{mV}$ ) compared with the three other brine-lake sediments $(-82$ to $-136 \mathrm{mV})[15]$. Here we provide evidence that Discovery Basin sediments have the lowest viable counts yet the highest endospore counts; also this, and a previous study [9], have shown that microbes could not be isolated, nor sub-cultured on media with $\mathrm{MgCl}_{2}$ concentrations approaching those found in Discovery brine. This suggests that a large proportion of the microbes in Discovery sediment are inactive, but leaves open the possibility 
of finding novel extremophiles specifically adapted to high concentrations of this extremely chaotropic salt.

We provide the first report of isolates from the deep-sea hypersaline brine-lake sediments, and while most did not have the potential to be active in situ, some isolates, clustering within the genus Pontibacillus, could grow at in-situ salinities and under anoxic conditions, either by respiration with dimethylsulfoxide or trimethylamine $\mathrm{N}$-oxide as electron acceptor (AS2, AS3, US13) or by fermentation (AS2, AS3). This confirms that the NaCl-dominated brinelake sediments contain active microbial populations as demonstrated in l'Atalante basin by leucine incorporation [14], and also supports the notion that the extremely high sulfide concentration in Urania brine lake $[5,6]$, known to inhibit even sulfate-reducing bacteria [46], allows microbial processes to continue. This study raises tantalizing questions about the origin, distribution, survival and metabolic activity of vegetative microbial cells and endospores in some of the most extreme environments on earth: why for example were 14 isolates with identical ARDRA profiles found only in Bannock and l'Atalante brine-lake sediments, the most geochemically similar, but geographically remote basins? Answers will come from further analysis of isolates to obtain a detailed understanding of their physiology, as well as nucleic-acid based studies of microbial communities and endospores in, around and above the brine-lake sediments as well inside Messinian rock salt.

\section{Methods}

\section{Site description and sampling procedures}

Four different brine lakes in the Eastern Mediterranean were sampled between $20^{\text {th }}$ and $31^{\text {st }}$ August 2001 on a cruise with the R/V Urania. Three of them, l'Atalante, Discovery and Urania basin, are situated very close to each other on the north-eastern edge of the Mediterranean Ridge [47], only a few kilometers apart, whereas the Bannock basin is located on the southern edge of the ridge [48] (Fig. 1). Samples from the upper two centimeters of the sediments were taken with a box corer (Discovery basin) or a multicorer (all other basins). Immediately after retrieval, the sediment was aseptically transferred into serum bottles. The headspace was flushed with oxygen-free nitrogen and sealed by means of butyl rubber stoppers. Until processing, the samples were stored in the dark at room temperature. Dilution series from the sediment samples were made with a sterile solution of $25 \%$ $\mathrm{NaCl}$.

\section{Enrichment, isolation and cultivation}

For enrichment and isolation of bacteria six different oxic media were used, representing a combination of three different salt concentrations and two mixtures of organic substrates. Medium B reflected the salt composition of the
Bannock basin [48]; the salinity was approximately $24 \%$.

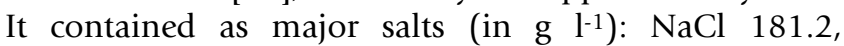
$\mathrm{MgCl} \cdot 6 \mathrm{H}_{2} \mathrm{O} 61, \mathrm{KCl} 7.5, \mathrm{CaCl}_{2} \cdot 2 \mathrm{H}_{2} \mathrm{O} 2.2, \mathrm{Na}_{2} \mathrm{SO}_{4}$ 14.2, $\mathrm{MgBr}_{2} \cdot 6 \mathrm{H}_{2} \mathrm{O} 1.2, \mathrm{H}_{3} \mathrm{BO}_{3}$ 0.3, TRIS 2.4. Minor constituents were added from stock solutions (in $\mathrm{mM}$ final concentration): $\mathrm{SrCl}_{2}$ 0.05, $\mathrm{LiCl} 0.075, \mathrm{NaF} 0.07, \mathrm{NH}_{4} \mathrm{Cl} 0.5$, $\mathrm{KH}_{2} \mathrm{PO}_{4}$ 0.1. One $\mathrm{ml}$ of a trace element solution (SL10, [49]) was added and the $\mathrm{pH}$ adjusted to 7.6 with $\mathrm{HCl}$. A solution of 10 vitamins [50] was added after autoclaving. Medium B/2 resembled medium B, but contained only half of the amount of the major salts. Medium SW consisted of artificial seawater which contained (in $\mathrm{g} \mathrm{l}^{-1}$ ): $\mathrm{NaCl} 24.3, \mathrm{MgCl}_{2} \cdot 6 \mathrm{H}_{2} \mathrm{O} 10, \mathrm{KCl} 0.75, \mathrm{CaCl}_{2} \cdot 2 \mathrm{H}_{2} \mathrm{O}$ 1.5, $\mathrm{Na}_{2} \mathrm{SO}_{4} 4$. The minor constituents, buffer and $\mathrm{pH}$ of the artificial seawater were as described above, additionally $\mathrm{MgBr}_{2}$ and $\mathrm{H}_{3} \mathrm{BO}_{3}$ were added from stock solutions to a final concentration of $0.4 \mathrm{mmol} \mathrm{l}^{-1}$ each.

The organic substrates are denoted as CPS (casamino acids $0.5 \mathrm{~g} \mathrm{l}^{-1}$, bactopeptone $0.5 \mathrm{~g} \mathrm{l}^{-1}$, soluble starch $0.5 \mathrm{~g}$ $\mathrm{l}^{-1}$, glycerol $13 \mathrm{mmol} \mathrm{l}^{-1}$ ) or as $\mathrm{M}$, a mixture of the following substrates (in $1 \mathrm{mM}$ final concentrations, $\mathrm{pH} 7$ ): glucose, glycerol, sodium acetate, sodium lactate, sodium fumarate, sodium succinate, alanine, glycine, sodium glutamate and sodium thiosulfate.

After six weeks of incubation at $20^{\circ} \mathrm{C}$ colonies from each positive plate were selected after their appearance, and isolated by streaking out repeatedly on the respective medium. Isolated strains were maintained on CPS-SW at $20^{\circ} \mathrm{C}$. The number of CFU ml-1 sediment was estimated from the mean number of colonies on the seawater-based medium with organic components CPS and $\mathrm{M}$, using the calculation of Cavalli-Sforza [51].

\section{Phenotypic characterization}

Tests for the presence of oxidase and catalase, Gram-staining and staining of flagella and spores were performed according to standard procedures [52]. For further enzyme tests the API 20 E-system (bioMérieux, Marcy L'Étoile, France; [53]) was used following the manufacturer's instructions. The degradation of Tween 80 and the following polymers was determined on CPS-SW agar (without starch) at $30^{\circ} \mathrm{C}$, unless indicated otherwise. All results were confirmed with two independent replicates of each test. Amylase activity was detected by zones of clearing around colonies on medium with $2 \mathrm{~g} \mathrm{l}^{-1}$ of soluble starch (BDH Laboratories) after flooding plates with Lugol's iodine solution. TWEEN 80 esterase activity was detected by formation of precipitate around colonies on medium containing 1\% w/v TWEEN 80 (BDH Laboratories). Gelatin liquefaction was tested by adding $12 \% \mathrm{w} / \mathrm{v}$ gelatin (Sigma ${ }^{\oplus}$, Type A; 300 Bloom) instead of agar to CPS-T-SW (excluding starch); the solidified medium was inoculated with a needle and incubated at room tempera- 
ture. Casein hydrolysis was demonstrated by zones of clearing around colonies on media to which $3 \mathrm{~g} \mathrm{l}^{-1}$ of sterile skimmed milk (autoclaved separately at $110^{\circ} \mathrm{C}$ for 40 min) had been added. Cellulase activity was detected by a zone of clearing around colonies after flooding plates containing $1 \% \mathrm{w} / \mathrm{v}$ low-viscosity carboxymethyl cellulose (Sigma) with $1 \mathrm{~g} \mathrm{l}^{-1}$ of Congo Red (Sigma). Ground chitin (50 g) from crab carapaces was dissolved by stirring for one hour in $2.5 \mathrm{l}$ of $32 \% \mathrm{HCl}$. The solution was filtered through a cloth before adding sufficient deionised water (approximately $20 \mathrm{l}$ ) to precipitate the chitin. The precipitate was washed by centrifugation, until a neutral $\mathrm{pH}$ was obtained. The prepared chitin $\left(0.5 \mathrm{~g} \mathrm{l}^{-1}\right)$ was added to CPS-T-SW (excluding starch) agar, and added as an overlay medium on top of standard CPS-T-SW, which was inoculated and incubated at $30^{\circ} \mathrm{C}$. Chitinase activity was detected by a hydrolytic zone appearing as clear halos around colonies. DNAse activity was detected by zones of clearing around colonies growing on DNase Test Agar (Merck) with added $\mathrm{NaCl}\left(19.4 \mathrm{~g} \mathrm{l}^{-1}\right)$ after flooding plates with $1 \mathrm{M} \mathrm{HCl}$.

Substrate utilization was tested in microtiter plates using liquid SW medium and the following compounds as sole carbon and energy source (final concentrations in brackets): (1) The poly- and disaccharides dextran, alginic acid, laminarin (each at $2 \mathrm{~g} \mathrm{l}^{-1}$ ), cellobiose, sucrose, maltose, lactose, and trehalose (each at $5 \mathrm{mM}$ ), (2) the monosaccharides and their derivates glucose, fructose, galactose, mannose, arabinose, ribose, xylose, rhamnose, N-acetylglucosamine, glucosamine, gluconic acid, sorbitol, mannitol (each at $10 \mathrm{mM}$ ) and meso-erythritol (20 mM), (3) the alcohols glycerol $(20 \mathrm{mM})$, methanol $(20 \mathrm{mM})$, ethanol $(20 \mathrm{mM}), n$-propanol $(10 \mathrm{mM})$ and $n$-butanol $(10$ $\mathrm{mM}),(4)$ the fatty acids formate $(20 \mathrm{mM})$, acetate $(20$ $\mathrm{mM})$, propionate $(10 \mathrm{mM})$ and butyrate $(10 \mathrm{mM}),(5)$ the carboxylic acids lactate, pyruvate, malate, succinate, fumarate, citrate (each at $20 \mathrm{mM}$ ) and $\alpha$-ketoglutarate $(10$ $\mathrm{mM}),(6)$ the 20 common amino acids glycine, alanine, cysteine, proline, serine, threonine, valine (at $20 \mathrm{mM}$ each), arginine, asparagine, aspartic acid, glutamine, glutamic acid, histidine, isoleucine, leucine, lysine, methionine, phenylalanine, tryptophan and tyrosine (at $10 \mathrm{mM}$ each), (7) miscellaneous compounds: betaine (20 $\mathrm{mM})$, benzoate $(10 \mathrm{mM})$ and salicylate $(10 \mathrm{mM}),(8)$ the complex substrates yeast extract, casamino acids and bactopeptone (each at $1 \mathrm{~g} \mathrm{l}^{-1}$ ), and (9) the $n$-alkanes, $n$ dodecane and $n$-hexadecane $(1 \% \mathrm{v} / \mathrm{v})$ as sole carbon and energy source were tested in oxic SW medium in sealed serum bottles. Growth was assessed visually after two weeks incubation at $30^{\circ} \mathrm{C}$.

The range for growth at different temperatures, salt concentrations and $\mathrm{pH}$ values was tested in liquid CPS-SW medium in glass test tubes. The medium was amended with yeast extract $\left(1 \mathrm{~g} \mathrm{l}^{-1}\right)$, and, below pH 7.0, PIPES (10 $\mathrm{mM}$ ) was used as a buffer instead of TRIS. The salt concentrations tested ranged from 0.1 to $30 \% \mathrm{w} / \mathrm{v} \mathrm{NaCl}$, with the other major salts at a concentration of $0.5 \mathrm{mM}$. Growth was measured by turbidity at $430 \mathrm{~nm}$.

Anaerobic growth was tested in screw cap bottles using liquid anoxic CPS-SW medium buffered with $\mathrm{NaHCO}_{3}$ (30 mM, autoclaved separately) replacing TRIS, $\mathrm{Na}_{2} \mathrm{~S}$ (2 $\mathrm{mM}$, autoclaved separately at $109^{\circ} \mathrm{C}$ ) as reducing agent, resazurin $\left(0.25 \mathrm{mg} \mathrm{l}^{-1}\right)$ as redox indicator, and filter-sterilized glucose $\left(4.5 \mathrm{~g} \mathrm{l}^{-1}\right)$ replacing starch.

\section{Cluster analysis}

The results of the 106 phenotypic tests were coded for numerical analysis in binary format and a similarity dendrogram was drawn using the XLSTAT ${ }^{\mathrm{TM}}$ software package (version 2008.1.02; Addinsoft, Paris, France) using the Agglomerative Hierarchical Clustering (AHC) method, calculated with the Jaccard coefficient and UPGA (unweighted pair-group average) linkage.

\section{Screening for different I6S rRNA phylotypes by Amplified Ribosomal DNA Restriction Analysis (ARDRA)}

Freshly grown colonies were suspended in $10 \mathrm{mM}$ TRIS, $\mathrm{pH} \mathrm{8,} \mathrm{centrifuged} \mathrm{and} \mathrm{washed.} \mathrm{The} \mathrm{cells} \mathrm{were} \mathrm{then} \mathrm{lysed}$ by five freeze-thaw cycles ( $1 \mathrm{~min}$ in liquid nitrogen, followed by $5 \mathrm{~min}$ at $\left.60^{\circ} \mathrm{C}\right)$. The lysate $(0.5-1 \mu \mathrm{l})$ was used directly in the PCR. The 16S rRNA genes were amplified in a Gene Amp PCR System (Applied Biosystems, Foster City, CA, USA) using 0.05 units $\cdot \mu \mathrm{l}^{-1}$ final concentration of TaqPol DNA polymerase (Qiagen, Crawley, UK). The primers used were 27F ( 5 '-AGA GTT TGA TCM TGG CTC AG-3') and 1492R (5'-TAC GGY TAC CTT GTT ACG ACT $\left.\mathrm{T}-3^{\prime}\right)$ with an annealing temperature of $55^{\circ} \mathrm{C}$. The PCR product was purified with the QIAquick system (Qiagen, Crawley, UK) and approximately $100 \mathrm{ng}$ of the cleaned product was digested for $2.5 \mathrm{~h}$ at $37^{\circ} \mathrm{C}$ with the restriction enzymes Alu I ( 1 unit $\cdot \mu l^{-1}$ final concentration, Roche Diagnostics, Mannheim, Germany). The resulting DNA fingerprints were analyzed after electrophoresis in a 3\% $\mathrm{w} / \mathrm{v}$ agarose gel $(1 \mathrm{~h}, 100 \mathrm{~V}, 100$ base pair ladder as standard) using a digital image analyzer and the Quantity One software package. One strain of each fingerprint-type was selected for partial sequencing of the 16S rRNA genes, and 25 strains with different ARDRA profiles and related to Bacillaceae were selected for phenotypic characterization.

\section{I6S rRNA gene sequencing and phylogenetic analysis}

Purified PCR products were subjected to sequence analysis using the ABI PRISM Big Dye Terminator Cycle Sequencing kit version 2.0 and an ABI 310 automatic sequencer (Applied Biosystems, Foster City, CA, USA). The primers used to obtain sequence fragments were $518 \mathrm{R}$ (5'-CGT ATT ACC GCG GCT GCT GG-3'), 338R (5'-CTG 
CTG CCT CCC GTA GGA GT-3'), 357F (5'-ACT CCT ACG GGA GGC AGC AG-3'), 907R (5'-CCG TCA ATT CMT TTR AGT TT-3'), 1389R (5'-ACG GGC GGT GTG TAC AAG-3'). Sequence fragments were checked using the Chromas 1.45 software package [54] and contigs assembled using BioEdit 5.0.9 [55]. Assembled 16S rRNA sequences were compared to the European Bioinformatics Institutes database by online FastA searches [56]. Multiple sequence alignment of the isolates and their closest relatives was performed using CLUSTAL W [57] and GeneDoc Multiple Sequence Alignment Editor version 2.6.002 [58]. Phylogenies were constructed based on an alignment of approximately $1340 \mathrm{bp}$, with the PHYLIP software package [59], using the Jukes and Cantor [60] model of nucleotide substitution, and the neighbour-joining algorithm. Significance of branching order was determined by bootstrap analysis with 1000 resampled data sets. Sequences were deposited in the EMBL databases with accession numbers AM950291 to AM950315.

\section{Determination of dipicolinic acid (DPA) and estimation of endospore numbers}

Numbers of endspores in sediment samples were estimated after extraction and analysis of dipicolinic acid (DPA), an endospore-specific biomarker [28]. Extraction and analysis were performed after Fichtel et al. [61]. In brief, $1.0 \mathrm{~g}$ of freeze-dried sediment was weighed into autoclavable 15-ml polypropylene tubes with screw caps. Duplicates were prepared for each sample to determine recovery: One of the sediment aliquots was suspended in

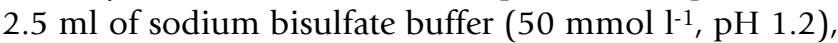
the other one was spiked by suspending in $2.5 \mathrm{ml}$ of buffer with 250 nmol DPA $~^{-1}$. Both duplicates were autoclaved to completely release DPA from the endospores within the sediment. After cooling, the samples were centrifuged $\left(4000 \mathrm{~g}, 5 \mathrm{~min}, 15^{\circ} \mathrm{C}\right)$, and the supernatants were filtered through cellulose acetate syringe filters $(0.2 \mu \mathrm{m}$ pore size, Nalgene Nunc International, Rochester, NY) into polypropylene vials. DPA concentrations were determined as Tb-dipicolinate complexes via HPLC with postcolumn complexation and fluorescence detection as described by Fichtel et al. [61]. Endospore numbers were estimated using an average cellular DPA content of $2.24 \times$ $10^{-16} \mathrm{~mol}$ per spore [28].

\section{Competing interests}

The authors declare that they have no competing interests.

\section{Authors' contributions}

TJM, KNT and AMS conceived the study, AMS sampled and obtained isolates, AMS and BAM performed most of the experimental work, JF performed DPA analysis. All were involved in developing the study and in the writing.

\section{Acknowledgements}

Members of the BIODEEP consortium, in particular the coordinator Cesare Corselli (CoNISMa, Milan) and the captain and crew of the research vessel Urania are gratefully acknowledged. We are indebted to Dr. John E. Hallsworth for useful discussions. The work was supported by the FP5 EC Project BIODEEP (Contract EVK3-2000-22057), with a contribution from the Society for General Microbiology summer vacation studentship scheme.

\section{References}

I. Camerlenghi A: Anoxic basins of the eastern Mediterranean: geological framework. Mar Chem 1990, 31 : I-19.

2. Hsü KJ, Montadert L, Bernoulli D, Cita MB, Erickson A, Garrison RE, Kidd RB, Mèlierés F, Müller C, Wright R: History of the Mediterranean salinity crisis. Nature 1977, 267:399-403.

3. Krijgsman W, Hilgen F], Raffi I, Sierro F], Wilson DS: Chronology, causes and progression of the Messinian salinity crisis. Nature 1999, 400:652-655.

4. De Lange GJ, Catalano G, Klinkhammer GP, Luther GW III: The interface between oxic seawater and the anoxic Bannock brine; its sharpness and the consequences for the redoxrelated cycling of Mn and Ba. Mar Chem 1990, 3I:205-2I7.

5. Wielen PWJJ van der, Bolhuis $H$, Borin S, Daffonchio D, Corselli $C$, Giuliano L, de Lange G], Huebner A, Varnavas SP, Thomson J, Tamburini C, Marty D, McGenity TJ, Timmis KN, Biodeep Scientific Party: The enigma of prokaryotic life in deep hypersaline anoxic basins. Science 2005, 307: 12I-123.

6. Sass AM, Sass H, Coolen MJL, Cypionka H, Overmann J: Microbial communities in the chemocline of a hypersaline deep-sea basin (Urania basin, Mediterranean Sea). Appl Environ Microbiol 200I, 67:5392-5402.

7. Corselli C, Basso D, de Lange G, Thomson J: Mediterranean Ridge accretionary complex yields rich surprises. EOS Transactions, American Geophysical Union 1996, 77:227-227.

8. Wallmann K, Suess E, Westbrook GH, Winckler G, Cita MB MEDRIFF Consortium: Salty brines on the Mediterranean seafloor. Nature 1997, 387:31-32.

9. Hallsworth JE, Yakimov MM, Golyshin PN, Gillion JLM, D'Auria G, de Lima Alves F, La Cono V, Genovese M, McKew BA, Hayes SL, Harris G, Giuliano L, Timmis KN, McGenity TJ: Limits of life in $\mathbf{M g C l}_{2-}$ containing environments: chaotropicity defines the window. Environ Microbiol 2007, 9:80I-8I3.

10. Henneke E, Luther GW III, de Lange G], Hoefs J: Sulphur speciation in anoxic hypersaline sediments from the eastern Mediterranean Sea. Geochim Cosmochim Acta 1997, 61:307-321.

II. Daffonchio D, Borin S, Brusa T, Brusetti L, Wielen PWJ] van der, Bolhuis H, D'Auria G, Yakimov M, Giuliano L, Tamburini C, Marty D, McGenity TJ, Hallsworth JE, Sass AM, Timmis KN, Tselepides A, de Lange G], Huebner A, Thomson J, Varnavas SP, Gasparoni F, Gerber HW, Malinverno E, Corselli C, Biodeep Scientific Party: Stratified prokaryote network in the oxic-anoxic transition of a deepsea halocline. Nature 2006, 440:203-207.

12. Yakimov MM, La Cono V, Denaro R, D'Auria G, Decembrini F, Timmis KN, Golyshin PN, Giuliano L: Primary producing prokaryotic communities of brine, interface and seawater above the halocline of deep anoxic lake L'Atalante, Eastern Mediterranean Sea. ISME J 2007, I:743-755.

13. Ferrer M, Golyshina OV, Chemikova TN, Khachane AN, dos Santos VAPM, Yakimov MM, Timmis KN, Golyshin PN: Microbial enzymes mined from the Urania deep-sea hypersaline anoxic basin. Chem Biol 2005, 12:895-904.

14. Danovaro R, Corinaldesi C, Dell'Anno A, Fabiano M, Corselli C: Viruses, prokaryotes and DNA in the sediments of a deephypersaline anoxic basin (DHAB) of the Mediterranean Sea. Environ Microbiol 2005, 7:586-592.

15. Polymenakou PN, Stephanou EG, Tselepides A, Bertilsson S: Organic matter preservation and microbial community accumulations in deep-hypersaline anoxic basins. Geomicrobiol | 2007, 24:19-29.

16. Brusa T, Del Puppo E, Ferrari A, Rodondi G, Andreis C, Pellegrini S: Microbes in deep-sea anoxic basins. Microbiol Res 1997, I52:45-56.

17. Brusa T, Borin S, Ferrari F, Sorlini C, Corselli C, Daffonchio D: Aromatic hydrocarbon degradation patterns and catechol 2,3- 
dioxygenase genes in microbial cultures from deep anoxic hypersaline lakes in the eastern Mediterranean sea. Microbiol Res 200I, 156:49-57.

18. La Ferla R, Crisafi E: Preliminary study on vertical distribution of microorganisms in the Bannock Basin waters (Eastern Mediterranean Sea). Mar Ecol Prog Ser 199I, 75:309-3II.

19. Wainwright M, Wickramasinghe NC, Narlikar JV, Rajaratnam P: Microorganisms cultured from stratospheric air samples obtained at 4I km. FEMS Microbiol Lett 2003, 218:16I-165.

20. Boone DR, Liu YT, Zhao ZJ, Balkwill DL, Drake GR, Stevens TO, Aldrich HC: Bacillus infernus sp. nov., an Fe(III)-reducing and Mn(IV)-reducing anaerobe from the deep terrestrial subsurface. Int J Syst Bacteriol 1995, 45:44I-448.

21. D'Hondt S, Jørgensen BB, Miller DJ, Batzke A, Blake R, Cragg BA, Cypionka H, Dickens GR, Ferdelman T, Hinrichs KU, Holm NG, Mitterer R, Spivack A, Wang G, Bekins B, Engelen B, Ford K, Gettemy G, Rutherford SD, Sass H, Skilbeck CG, Aiello IW, Guèrin G, House C, Inagaki F, Meister P, Naehr T, Niitsuma S, Parkes RJ, Schippers A, Smith DC, Teske A, Wiegel J, Naranjo Padilla C, Solis Acosta JL: Distributions of microbial activities in deep subseafloor sediments. Science 2004, 306:2216-2221.

22. Batzke A, Engelen B, Sass H, Cypionka H: Phylogenetic and physiological diversity of cultured deep-biosphere bacteria from equatorial Pacific Ocean and Peru Margin sediments. Geomicrobiol J 2007, 24:26I-273.

23. Nicholson WL, Munakata N, Horneck G, Melosh H, Setlow P: Resistance of Bacillus endospores to extreme terrestrial and extraterrestrial environments. Microbiol Mol Biol Rev 2000, 64:548-572.

24. Sass AM: Microbial communities at oxic-anoxic interfaces. In $\mathrm{PhD}$ thesis University of Oldenburg, Department of Biology, Geo and Environmental Sciences; 200I.

25. Stackebrandt E, Swiderski J: From phylogeny to systematics: the dissection of the genus Bacillus. In Applications and systematics of Bacillus and relatives Edited by: Berkeley R, Heyndrickx M, Logan N, De Vos P. Malden, MA: Blackwell Science; 2002:8-22

26. Lim J-M, Jeon CO, Song SM, Kim C-J: Pontibacillus chungwhensis gen. nov., sp. nov., a moderately halophilic Gram-positive bacterium from a solar saltern in Korea. Int J System Evol Microbiol 2005, 55:165-170.

27. Rütters H, Sass H, Cypionka H, Rullkötter J: Microbial communities in a Wadden Sea sediment core - clues from analyses of intact glyceride lipids, and released fatty acids. Org Geochem 2002, 33:803-816.

28. Fichtel J, Köster J, Rullkötter J, Sass H: Spore dipicolinic acid contents used for estimating the number of endospores in sediments. FEMS Microbiol Ecol 2007, 61:522-532.

29. Slepecky RA, Hemphil HE: The genus Bacillus - nonmedical. In The Prokaryotes 2 nd edition. Edited by: Balows A, Trüper HG, Dworkin M, Harder W, Schleifer KH. New York: Springer; 1992:1663-1695

30. Garabito MJ, Márquez MC, Ventosa A: Halotolerant Bacillus diversity in hypersaline environments. Can J Microbiol 1998, 44:95-102.

31. Ventosa A, Márquez MC, Garabito MJ, Arahal DR: Moderately halophilic gram-positive bacterial diversity in hypersaline environments. Extremophiles 1998, 2:297-304.

32. Marteinsson VT, Birrien J-L, Jeanthon C, Prieur D: Numerical taxonomic study of thermophilic Bacillus isolated from three geographically separated deep-sea hydrothermal vents. FEMS Microbiol Ecol 1996, 21:255-266.

33. Laiz L, Piñar G, Lubitz W, Saiz-Jimenez C: Monitoring the colonization of monuments by bacteria: cultivation versus molecular methods. Environ Microbiol 2003, 5:72-74.

34. Miskin I, Rhodes G, Lawlor K, Saunders JR, Pickup RW: Bacteria in post-glacial freshwater sediments. Microbiology 1998, 1 44:2427-2439.

35. Straskrabova V: The effect of substrate shock on populations of starving aquatic bacteria. J Appl Bact 1983, 54:217-224.

36. Macnaughton SJ, Jenkins TL, Wimpee MH, Cormier MR, White DC: Rapid extraction of lipid biomarkers from pure culture and environmental samples using pressurized accelerated hot solvent-extraction. J Microbiol Meth 1997, 3 1:19-27.

37. Rosson RA, Nealson KH: Manganese binding and oxidation by spores of a marine bacillus. J Bacteriol 1982, I 5 I: 1027-1034
38. Cano RJ, Borucki MK: Revival and identification of bacterial spores in 25- to 40-million-year-old Dominican amber. Science 1995, 268: 1060-1064.

39. Vreeland RH, Rosenzweig WD, Powers DW: Isolation of a 250 million-year-old halotolerant bacteriom from a primary salt crystal. Nature 2000, 407:897-900.

40. Christner BC, Mosley-Thompson E, Thompson LG, Zagorodnov V Sandman K, Reeve JN: Recovery and identification of viable bacteria immured in glacial ice. Icarus 2000, I44:479-485.

4I. Christner BC, Mosley-Thompson E, Thompson LG, Reeve JN: Bacterial recovery from ancient glacial ice. Environ Microbiol 2003, 5:433-436.

42. McGenity TJ, Gemmell RT, Grant WD, Stan-Lotter H: Origins of halophilic microorganisms in ancient salt deposits. Environ Microbiol 2000, 2:243-250.

43. Tehei M, Franzetti B, Maurel M-C, Vergne J, Hountondji C, Zaccai G: The search for traces of life: the protective effect of salt on biological macromolecules. Extremophiles 2002, 6:427-430.

44. Süß J, Engelen B, Cypionka H, Sass $\mathrm{H}$ : Quantitative analysis of bacterial communities from Mediterranean sapropels based on cultivation-dependent methods. FEMS Microbiol Ecol 2004 51:109-121.

45. SüßJ, Schubert K, Sass H, Cypionka H, Overmann J, Engelen B: Widespread distribution and high abundance of Rhizobium radiobacter within Mediterranean subsurface sediments. Environ Microbiol 2006, 8:1753-1763.

46. O'Flaherty V, Mahony T, O'Kennedy R, Colleran E: Effect of pH on growth kinetics and sulphide toxicity thresholds of a range of methanogenic, syntrophic and sulphate-reducing bacteria. Proc Biochem 1998, 33:555-569.

47. MEDRIFF Consortium: Three brine lakes discovered in the seafloor of the Eastern Mediterranean. EOS Transactions, American Geophysical Union 1996, 76:315-320.

48. De Lange G], Middelburg IJ, Weijden $\mathrm{CH}$ van der, Catalano $\mathrm{G}$, Luther GW III, Hyds DJ, Woittiez JRW, Klinkhammer GP: Composition of anoxic hypersaline brines in the Tyro and Bannock Basins, eastern Mediterranean. Mar Chem 1990, 31:63-88.

49. Widdel F, Kohring G-W, Mayer F: Studies on dissimilatory sulfate-reducing bacteria that decompose fatty acids. III. Characterization of the filamentous gliding Desulfonema limicola gen. nov. sp. nov., and Desulfonema magnum sp. nov. Arch Microbiol 1983, I 34:286-294

50. Balch WE, Fox GE, Magrum LJ, Woese CR, Wolfe RS: Methanogens: reevaluation of a unique biological group. Microbiol Rev 1979, 43:260-296.

5I. Cavalli-Sforza L: Biometrie Stuttgart: Gustav Fischer Verlag; 1972.

52. Gerhardt P, Murray RGE, Wood WA, Krieg NR: Methods for general and molecular bacteriology 2nd edition. Washington D.C.: ASM; 1994.

53. Logan NA, Berkeley RCW: Identification of Bacillus strains using the API system. J Gen Microbiol 1984, I 30: 187|- 882

54. McCarthy C: Chromas version 1.45 Southport, Australia: School of Health Science, Griffith University; 1998.

55. Hall TA: BioEdit: a user-friendly biological sequence alignment editor and analysis program for Windows 95/98/NT. Nucl Acids Symp Ser 1999, 41:95-98.

56. Pearson WR: Rapid and sensitive sequence comparison with FASTP and FASTA. Meth Enzymol 1990, 183:63-98.

57. Thompson JD, Higgins DG, Gibson T): CLUSTAL W: Improving the sensitivity of progressive multiple sequence alignment through sequence weighting, positions-specific gap penalties and weight matrix choice. Nucleic Acids Res 1994, 22:4673-4680.

58. Nicholas KB, Nicholas HB, Deerfield DW II: GeneDoc: a tool for editing and annotating multiple sequence alignments. Volume 4. EMBNEW News; 1997:14

59. Felsenstein J: PHYLIP - Phylogeny Inference Package (Version 3.2). Cladistics 1989, 5:164-166.

60. Jukes TH, Cantor CR: Evolution of protein molecules. In Mammalian Protein Metabolism Edited by: Munro H. New York: Academic Press; 1969:21-132

6I. Fichtel J, Köster J, Scholz-Böttcher B, Sass H, Rullkötter J: A highly sensitive HPLC method for determination of nanomolar concentrations of dipicolinic acid, a characteristic constituent of bacterial endospores. I Microbiol Methods 2007 , 70(2):319-327. 